\title{
PARAMETRIC OPTIMIZATION OF EXTRUDED POLYPROPYLENE ROD AND ITS INVESTIGATION USING FINITE ELEMENT ANALYSIS
}

\author{
Parminder Singh $^{1}$, Aprinder Singh Sandhu ${ }^{2}$, Saurabh Malpotra ${ }^{3}$, Amrinder Singh Pannu ${ }^{\mathbf{4}}$ \\ ${ }^{I}$ M-Tech student, Mechanical and Production Engineering Department, GNDEC Ludhiana \\ ${ }^{2}$ Assistant Professor, Mechanical Engineering Department, GNDEC Ludhiana \\ ${ }^{3}$ M-Tech student, Mechanical and Production Engineering Department, GNDEC Ludhiana \\ ${ }^{4}$ Assistant Professor, Mechanical Engineering Department, GNDEC Ludhiana
}

\begin{abstract}
Single screw extrusion is one of the key operations in plastic manufacturing industry. There are many process parameters of single screw extruder namely, die temperature, barrel temperature, screw speed and composition. These parameters and their interaction have been investigated by different researcher for better quality outcomes. The present work studies the influence of three main process parameter namely, dies temperature, barrel temperature and screw speed on the mechanical properties of polypropylene (M-12RR grade) rods. The critical process parameters were optimized using Taguchi L9 orthogonal array and analysis of variance for achieving high tensile strength and \% elongation. Further, the optimized results have been investigated using ANSYS FLUENT 15.0 software. The results of the study reveal that screw speed is the most contributing factor to control tensile strength and \%elongation, the least contributing factor is barrel temperature. The effect of process parameters on the fluid flowing inside the die of single screw extruder were investigated using CFD analysis.
\end{abstract}

Keywords: Single screw extrusion, Polypropylene (M-12RR), Taguchi L9 orthogonal array, Computational fluid dynamics

\section{INTRODUCTION}

Plastics are widely used all over the world primarily due to their superior properties such as high strength to weight ratio, high chemical/corrosive resistance, non conductivity, high clarity, low cost etc.

Polypropylene with its numerous applications such as to produce umbrella rods, hanger rods, chair legs, fan rod etc is widely used in industry. Due to its various applications, industries are more concerned about producing defect free, high strength of polypropylene materials.

Single screw extrusion is used to create objects of fixed cross-sectional profiles. It consists of barrel, motor, Die, controllers, thermocouples. There are four process parameters in single screw-extruder: - Barrel temperature, Die Temperature, Speed, Material compositions.

As the extrusion process studied and improved universally, still it is having some problems with the end product such as rough surface, extruder surging, thickness variation, uneven wall thickness, diameter variation and low tensile strength etc.

There are many parameters on which the extrusion process depends. To ensure successful extrusion manufacturing various process parameters must be identified, controlled, and monitored.
Taguchi method is most commonly used optimization technique. It was developed by Genichi Taguchi in 1920. It is a statistical method used to improve the quality of manufactured goods. To reduce the number of experiments to a practical level, only a small set from all the possibilities is selected. The method of selecting a limited number of experiments which produces the most information is known as a partial fraction experiment.

ANSYS gives a far reaching suite of computational fluid dynamics programming for demonstrating fluid stream and other related physical wonders. The ANSYS-FLUENT workbench15.0 is used to evaluate the behavior of fluid flowing inside the die and determine the significant parameters affecting the fluid flowing inside the die (Baalaganapathy Manohar., 2016).

\section{EXPERIMENTATION}

The pilot experimentation and literature survey has been performed to prepare an extruded rod. The first step was to check the possibility of preparation of Polypropylene (M$12 \mathrm{RR}$ grade) rod by varying input parameters such as barrel temperature, die temperature and screw speed to get the maximum possible tensile strength and \% elongation. The process variables of single screw extruder is barrel temperature $180^{\circ} \mathrm{C}$, die temperature $190^{\circ} \mathrm{C}$ and screw speed of $30 \mathrm{rpm}$ is randomly selected but obtained rod was irregular in shape, size and appearance, due to burning of material inside the die at high temperature and low speed. In this experimentation, Taguchi L9 orthogonal array was 
selected for design of experimentation. The process variables were chosen as availability on single-screw extruder, as barrel temperature, die temperature and rpm of the extruder screw. The barrel temperature was taken at 3 different levels of 160,165 and $170^{\circ} \mathrm{C}$ and the die temperature of $155,160,165^{\circ} \mathrm{C}$ and $\mathrm{rpm}$ of extruder screw was taken as $45,50,55 \mathrm{rpm}$ and after that extruded rods was prepared according to the Taguchi L9 orthogonal array.

Table-1: Parameter selection for experimentation

\begin{tabular}{|l|l|l|l|}
\hline Levels & $\begin{array}{l}\text { Mean Barrel } \\
\text { temperature } \\
\left({ }^{\circ} \text { C) }\right.\end{array}$ & $\begin{array}{l}\text { Mean Die } \\
\text { temperature } \\
\left({ }^{\circ} \text { C) }\right.\end{array}$ & $\begin{array}{l}\text { Screw } \\
\text { speed } \\
(\text { rpm })\end{array}$ \\
\hline 1. & 160 & 155 & 40 \\
\hline 2. & 165 & 160 & 45 \\
\hline 3. & 170 & 165 & 50 \\
\hline
\end{tabular}

Table 1 shows the selected process parameters and their level for the final experimentation.

Table 2 shows the design of experiment using L9 orthogonal array. The investigations for tensile properties and \% elongation were analyzed on universal tensile testing machine.

Table-2: Design of experiment using L9 OA

\begin{tabular}{|l|l|l|l|}
\hline $\begin{array}{l}\text { Experime } \\
\text { nt no. }\end{array}$ & $\begin{array}{l}\text { Mean barrel } \\
\text { temperature } \\
\left({ }^{\circ} \mathbf{C}\right)\end{array}$ & $\begin{array}{l}\text { Mean die } \\
\text { temperatur } \\
\left.\text { e ( }{ }^{\circ} \mathbf{C}\right)\end{array}$ & $\begin{array}{l}\text { Screw } \\
\text { speed in } \\
\text { rpm }\end{array}$ \\
\hline 1. & 160 & 155 & 40 \\
\hline 2. & 160 & 160 & 45 \\
\hline 3. & 160 & 165 & 50 \\
\hline 4. & 165 & 155 & 45 \\
\hline 5. & 165 & 160 & 50 \\
\hline 6. & 165 & 165 & 40 \\
\hline 7. & 170 & 155 & 50 \\
\hline 8. & 170 & 160 & 40 \\
\hline 9. & 170 & 165 & 45 \\
\hline
\end{tabular}

\subsection{Boundary Conditions for CFD Analysis}

Ansys Workbench15.0 was used for investigate the contribution of process parameters inside the die of single screw extruder. The design model of die was made in design modeler of Workbench. The fluid was flowing inside the die using fill cavity command. The investigation was made for the effect of parameters on the fluid flowing inside the die. The die was split into 2 portions for supply heat from the 2 heating coils individually and a heater was controlled by controllers.

A very fine mesh was generated in FLUENT meshing part. Large number of fine mesh gives very accurate results. The final mesh contained, for die no. of nodes is 53856 and elements are 44760, for part fluid flow no. of nodes is 34593 and elements are 168282 so, the overall domain mesh having 88449 nodes and 213042 elements. For investigation of parameters in single screw extruder using CFD, the level which is having high tensile strength and \% Elongation is chosen.
For boundary condition, the parameter under level 3 was selected which is combination of barrel temperature is $160^{\circ} \mathrm{C}$, die temperature is $165^{\circ} \mathrm{C}$ and screw speed is $50 \mathrm{rpm}$.

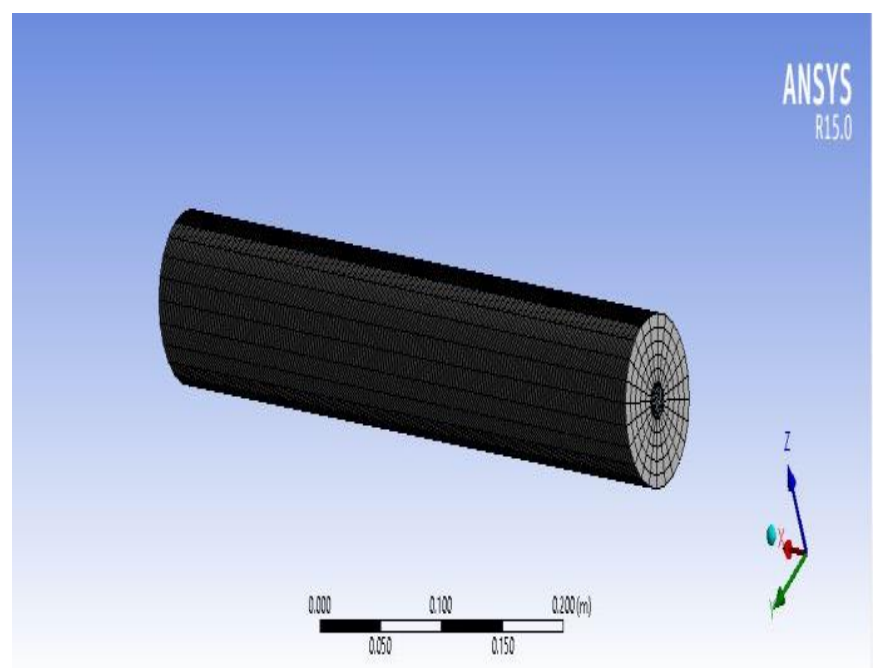

Fig-1: Part die with mesh

The mass flow rate of Polypropylene inside the die is 2.6456 $\mathrm{g} / 10 \mathrm{~min}$. There are 4 band heaters was connected with two controllers.

\section{RESULT AND DISCUSSION}

After effective pilot experimentation at characterized level of process factors, Polypropylene (M-12RR grade) were set up according to Taguchi L9 orthogonal array, the outcomes for the distinctive yield parameters (to be specific: tensile strength and $\%$ elongation) discussed.

\subsection{Tensile Strength at Peak}

Table 3 shows the output of peak tensile strength for different parametric conditions based upon Taguchi L9 orthogonal array. The maximum value of peak tensile strength was occurred for sample no. 03, in which the parametric conditions are barrel temperature $160^{\circ} \mathrm{C}$, Die temperature $165^{\circ} \mathrm{C}$ and screw speed $50 \mathrm{rpm}$. At this level moderate temperature and high screw speed gives good results. The minimum value obtained for sample no. 1, which is the parametric conditions are barrel temperature $160^{\circ} \mathrm{C}$, die temperature $155^{\circ} \mathrm{C}$ and screw speed $40 \mathrm{rpm}$.

Table-3: Outcome of peak tensile strength for different parametric conditions

\begin{tabular}{|l|l|l|l|l|l|}
\hline $\begin{array}{l}\text { Exp } \\
\text { erim } \\
\text { ent } \\
\text { no }\end{array}$ & $\begin{array}{l}\text { A } \\
\text { Mean } \\
\text { Barrel } \\
\text { tempe } \\
\text { rature } \\
\left({ }^{\circ} \mathbf{C}\right)\end{array}$ & $\begin{array}{l}\text { B } \\
\text { Mean } \\
\text { Die } \\
\text { tempe } \\
\text { rature } \\
\left({ }^{\circ} \mathbf{C}\right)\end{array}$ & $\begin{array}{l}\text { C } \\
\text { Screw } \\
\text { speed } \\
(\mathbf{r p m})\end{array}$ & $\begin{array}{l}\text { Tensil } \\
\text { e } \\
\text { streng } \\
\text { th } \\
(\text { MPa })\end{array}$ & $\begin{array}{l}\text { SN } \\
\text { ratio }\end{array}$ \\
\hline 1. & 160 & 155 & 40 & 23.741 & 27.5100 \\
\hline 2. & 160 & 160 & 45 & 24.512 & 27.7876 \\
\hline 3. & 160 & 165 & 50 & 25.946 & 28.2814 \\
\hline 4. & 165 & 155 & 45 & 24.230 & 27.6871 \\
\hline 5. & 165 & 160 & 50 & 24.285 & 27.7068 \\
\hline
\end{tabular}




\begin{tabular}{|l|l|l|l|l|l|}
\hline 6. & 165 & 165 & 40 & 25.734 & 28.2101 \\
\hline 7. & 170 & 155 & 50 & 24.535 & 27.7957 \\
\hline 8. & 170 & 160 & 40 & 24.657 & 27.8388 \\
\hline 9. & 170 & 165 & 45 & 25.850 & 28.2492 \\
\hline
\end{tabular}

The Fig. 2, below shows that the SN ratio first slightly increase and increase at faster rate with barrel temperature resulted into least effect on $\mathrm{SN}$ ratio. The $\mathrm{SN}$ ratio for die temperature was first increase and then increase abruptly with increase in die temperature which resulted into significant effect on $\mathrm{S} / \mathrm{N}$ ratio. $\mathrm{SN}$ ratio for screw speed is increases almost linearly. Again SN ratio is increase with screw speed sharply so, the effect of $\mathrm{SN}$ ratio at this parameter is moderate.

The main plot of SN ratio gives the proper justification that with increase in temperature and decrease in screw speed there will be increase in tensile strength.

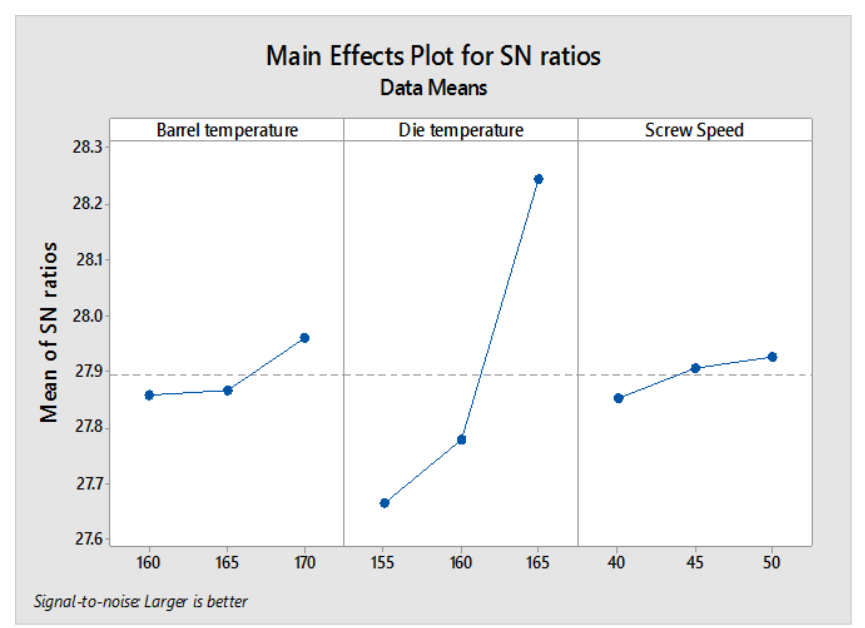

Fig- 2: Main effect plot of $\mathrm{S} / \mathrm{N}$ ratio for tensile strength

Table 4 shows that die temperature has rank 1 so it has maximum impact for contributions in $\mathrm{SN}$ ratios whereas screw speed has minimum impact so it is least significant.

Table-4: Response Table for Signal to Noise Ratios Larger is better

\begin{tabular}{|l|l|l|l|}
\hline Level & $\begin{array}{l}\text { Barrel } \\
\text { temperatur } \\
e\left({ }^{\circ} \mathrm{C}\right)\end{array}$ & $\begin{array}{l}\text { Die } \\
\text { temperature } \\
\left({ }^{\circ} \mathrm{C}\right)\end{array}$ & $\begin{array}{l}\text { Screw } \\
\text { speed } \\
(\text { rpm })\end{array}$ \\
\hline 1. & 27.86 & 27.66 & 27.85 \\
\hline 2. & 27.87 & 27.78 & 27.91 \\
\hline 3. & 27.96 & 28.25 & 27.93 \\
\hline Delta & 0.10 & 0.58 & 0.07 \\
\hline Rank & 2 & 1 & 3 \\
\hline
\end{tabular}

The below table 5 shows that the percentage error was found to be $3.95 \%$ for tensile strength. It shows that model has greater degree of precise. For optimization following formula based upon Taguchi design has been used:
Where ' $R$ ' is the overall mean of $S / N$ ratio data, $R_{A 3}$ is the mean of $S / N$ ratio data for barrel temperature at level 3 is maximum and $R_{B 3}$ is the mean of $S / N$ ratio data for die temperature at level 3 and $R_{C 3}$ is the mean of $S / N$ ratio data for screw speed at level 3 .

Table-6: Modified ANOVA table for tensile strength

\begin{tabular}{|c|c|c|c|c|c|c|c|}
\hline $\begin{array}{l}\text { Sourc } \\
\mathrm{e}\end{array}$ & $\begin{array}{l}\mathrm{D} \\
\mathrm{F}\end{array}$ & $\begin{array}{l}\text { Seq } \\
\text { SS }\end{array}$ & $\begin{array}{l}\text { Adj } \\
\text { SS }\end{array}$ & $\begin{array}{l}\text { Adj } \\
\text { MS }\end{array}$ & $\mathrm{F}$ & $\mathrm{P}$ & $\begin{array}{l}\% \\
\text { Co } \\
\text { ntri } \\
\text { buti } \\
\text { on }\end{array}$ \\
\hline $\begin{array}{l}\text { Barrel } \\
\text { temp. }\end{array}$ & 2 & $\begin{array}{l}0.0190 \\
86\end{array}$ & $\begin{array}{l}0.01 \\
9086\end{array}$ & $\begin{array}{l}0.009 \\
543\end{array}$ & $\begin{array}{l}0 . \\
77\end{array}$ & $\begin{array}{l}0.5 \\
66\end{array}$ & 3.1 \\
\hline $\begin{array}{l}\text { Die } \\
\text { temp. }\end{array}$ & 2 & $\begin{array}{l}0.5725 \\
27\end{array}$ & $\begin{array}{l}0.57 \\
2527\end{array}$ & $\begin{array}{l}0.286 \\
264\end{array}$ & $\begin{array}{l}23 \\
.0 \\
1\end{array}$ & $\begin{array}{l}0.0 \\
42\end{array}$ & $\begin{array}{l}91 . \\
5\end{array}$ \\
\hline $\begin{array}{l}\text { Screw } \\
\text { speed }\end{array}$ & 2 & $\begin{array}{l}0.0090 \\
46\end{array}$ & $\begin{array}{l}0.00 \\
9046\end{array}$ & $\begin{array}{l}0.004 \\
523\end{array}$ & $\begin{array}{l}0 . \\
36\end{array}$ & $\begin{array}{l}0.7 \\
33\end{array}$ & $\begin{array}{l}1.4 \\
5\end{array}$ \\
\hline $\begin{array}{l}\text { Resid } \\
\text { u-al } \\
\text { Error }\end{array}$ & 2 & $\begin{array}{l}0.0248 \\
83\end{array}$ & $\begin{array}{l}0.02 \\
4883\end{array}$ & $\begin{array}{l}0.012 \\
441\end{array}$ & & & $\begin{array}{l}3.9 \\
5\end{array}$ \\
\hline Total & 8 & $\begin{array}{l}0.6255 \\
42\end{array}$ & $\begin{array}{l}0.01 \\
9086\end{array}$ & & & & \\
\hline
\end{tabular}

$\mathrm{y}^{2}{ }_{\text {opt }}=(10)^{\text {nopt } / 10}$ for properties, greater is better

Calculation, overall mean of $\mathrm{SN}$ ratio $(\mathrm{t})$ was taken from Minitab software17.0.

$\mathrm{R}=27.8963$

Therefore, nopt $=28.3474$

$\mathrm{y}^{2}{ }_{\text {opt }}=(10)^{\text {nopt } / 10}$ for properties, greater is better

Therefore, yopt $=26.143$

So, Optimum Tensile strength at Peak $=26.143 \%$.

\subsection{Percentage Elongation at Peak}

As table 6 shows the output of $\%$ Elongation at peak for different process parametric conditions based upon Taguchi L9 OA. The maximum value of peak \%Elongation occurred for sample no. 3 , which is the combination of parameters barrel temperature $160^{\circ} \mathrm{C}$, die temperature $165^{\circ} \mathrm{C}$ and screw speed of 50rpm. The minimum value obtained for sample no. 7 , which is having the process parametric conditions of barrel temperature of $170^{\circ} \mathrm{C}$, die temperature of $155^{\circ} \mathrm{C}$ and screw speed of 50rpm. 
Table-6: Outcome of peak Percentage elongation for different parametric conditions

\begin{tabular}{|c|c|c|c|c|c|}
\hline $\begin{array}{l}\text { Parametri } \\
c \\
\text { Condition }\end{array}$ & $\begin{array}{l}\text { A. } \\
\text { Barre } \\
l \\
\text { Temp } \\
\cdot \\
(\text { in } \\
\left.{ }^{\circ} C\right)\end{array}$ & $\begin{array}{l}\text { B. } \\
\text { Die } \\
\text { Temp } \\
\cdot \\
(\text { in } \\
{ }^{o} \text { C) }\end{array}$ & $\begin{array}{l}\text { Scre } \\
w \\
\text { Spee } \\
d \\
(\text { rpm })\end{array}$ & $\begin{array}{l}\text { \% } \\
\text { Elongatio } \\
n\end{array}$ & $\begin{array}{l}\text { S/N } \\
\text { Ratio }\end{array}$ \\
\hline 1. & 160 & 155 & 40 & 5.102 & $\begin{array}{l}14.154 \\
8\end{array}$ \\
\hline 2. & 160 & 160 & 45 & 5.391 & $\begin{array}{l}14.633 \\
4\end{array}$ \\
\hline 3. & 160 & 165 & 50 & 5.504 & $\begin{array}{l}14.813 \\
6\end{array}$ \\
\hline 4. & 165 & 155 & 45 & 4.945 & $\begin{array}{l}13.883 \\
3\end{array}$ \\
\hline 5. & 165 & 160 & 50 & 5.419 & $\begin{array}{l}14.678 \\
4\end{array}$ \\
\hline 6. & 165 & 165 & 40 & 5.285 & $\begin{array}{l}14.460 \\
9\end{array}$ \\
\hline 7. & 170 & 155 & 50 & 4.835 & $\begin{array}{l}13.687 \\
9\end{array}$ \\
\hline 8. & 170 & 160 & 40 & 5.127 & $\begin{array}{l}14.197 \\
3\end{array}$ \\
\hline 9. & 170 & 165 & 45 & 5.302 & $\begin{array}{l}14.488 \\
8 \\
\end{array}$ \\
\hline
\end{tabular}

The figure 3 shows that the SN ratios decrease sharply as barrel temperature increased. The $\mathrm{SN}$ ratio for die temperature was first increase sharply with die temperature and furthers it increase slightly with die temperature, but the increasing trend was not sharp.

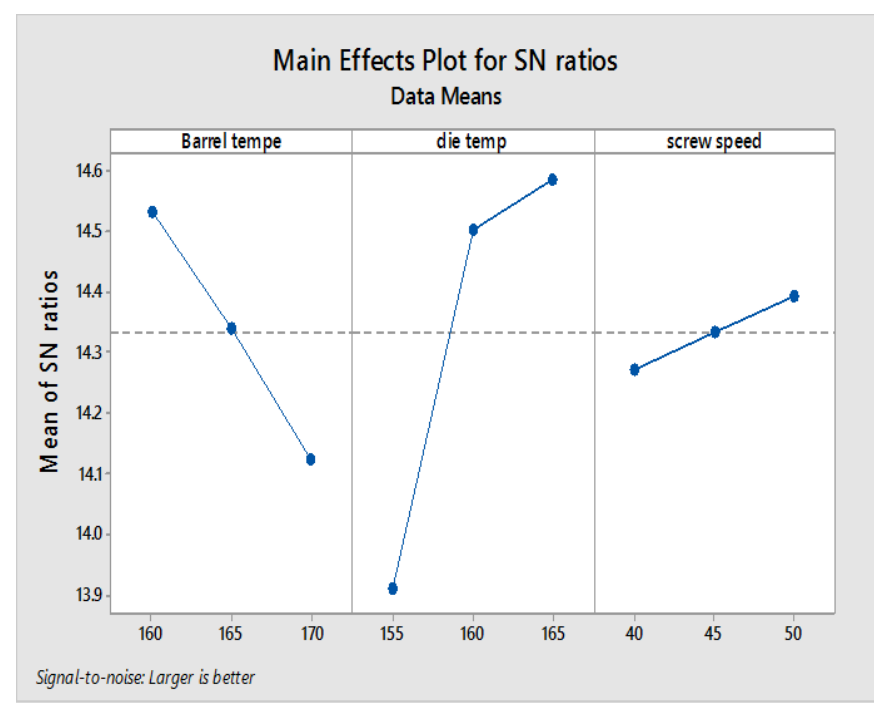

Fig-3: Main effect plot of $\mathrm{S} / \mathrm{N}$ ratio for \%Elongation

$\mathrm{SN}$ ratio for screw speed is increase sharply with increase in screw speed results increase in SN ratio. The lower speed and higher temperature gives better \% Elongation.

Table 7 shows that die temperature has maximum contribution impact on $\mathrm{SN}$ ratios whereas screw speed has minimum contributions impact.
Table-7: Response Table for Signal to Noise Ratios for \% Elongation Larger is better

\begin{tabular}{|l|l|l|l|}
\hline Level & $\begin{array}{l}\text { Barrel } \\
\text { temperature }\left({ }^{\circ} \mathrm{C}\right)\end{array}$ & $\begin{array}{l}\text { Die } \\
\text { temperature }\left({ }^{\circ} \mathrm{C}\right)\end{array}$ & $\begin{array}{l}\text { Screw } \\
\text { speed } \\
(\text { rpm })\end{array}$ \\
\hline 1. & 14.53 & 13.91 & 14.27 \\
\hline 2. & 14.34 & 14.50 & 14.34 \\
\hline 3. & 14.12 & 14.59 & 14.39 \\
\hline Delta & 0.41 & 0.68 & 0.12 \\
\hline Rank & 2 & 1 & 3 \\
\hline
\end{tabular}

From table no 08 error percentage found to be $4.71 \%$. The maximum contribution of $71.46 \%$ was found for die temperature. And the total contribution of existing three parameters is $95.29 \%$. The significant parameter is die temperature which is having maximum contribution factor among other parameters.

Table-8: Modified ANOVA table for \% Elongation

\begin{tabular}{|c|c|c|c|c|c|c|c|}
\hline Source & $\begin{array}{l}D \\
F\end{array}$ & $\begin{array}{l}\text { Seq } \\
\text { SS }\end{array}$ & $\begin{array}{l}\text { Adj } \\
S S\end{array}$ & $\begin{array}{l}\text { Adj } \\
M S\end{array}$ & $F$ & $P$ & $\begin{array}{l}\% \\
\text { Contr } \\
\text { ibutio } \\
n\end{array}$ \\
\hline $\begin{array}{l}\text { Barrel } \\
\text { temperat } \\
\text { ure }\end{array}$ & 2 & $\begin{array}{l}0.25 \\
151\end{array}$ & $\begin{array}{l}0.25 \\
151\end{array}$ & $\begin{array}{l}0.12 \\
575\end{array}$ & $\begin{array}{l}4.6 \\
5\end{array}$ & $\begin{array}{l}0 . \\
1 \\
7 \\
7\end{array}$ & 21.88 \\
\hline $\begin{array}{l}\text { Die } \\
\text { temperat } \\
\text { ure }\end{array}$ & 2 & $\begin{array}{l}0.82 \\
153\end{array}$ & $\begin{array}{l}0.82 \\
153\end{array}$ & $\begin{array}{l}0.41 \\
077\end{array}$ & $\begin{array}{l}15 . \\
18\end{array}$ & $\begin{array}{l}0 . \\
0 \\
6 \\
2\end{array}$ & 71.46 \\
\hline $\begin{array}{l}\text { Screw } \\
\text { speed }\end{array}$ & 2 & $\begin{array}{l}0.02 \\
245\end{array}$ & $\begin{array}{l}0.02 \\
245\end{array}$ & $\begin{array}{l}0.01 \\
123\end{array}$ & $\begin{array}{l}0.4 \\
2\end{array}$ & $\begin{array}{l}0 . \\
7 \\
0 \\
7\end{array}$ & 1.95 \\
\hline $\begin{array}{l}\text { Residual } \\
\text { Error }\end{array}$ & 2 & $\begin{array}{l}0.05 \\
410\end{array}$ & $\begin{array}{l}0.05 \\
410\end{array}$ & $\begin{array}{l}0.02 \\
705\end{array}$ & & & \\
\hline Total & 8 & $\begin{array}{l}1.14 \\
960\end{array}$ & & & & & \\
\hline
\end{tabular}

\subsection{CFD Analysis}

The temperature profile of sample number 03 is variable across the die, at inlet the temperature is high due to the high barrel temperature $\left(438^{\circ} \mathrm{K}\right)$ which transfer the heat to the die due to which the overall temperature at inlet is hike. There are four zones of temperature in the range of 438, 436, 435, 433 and $428^{\circ} \mathrm{K}$. In the first zone from $438-436$ the high temperature zone is in a stream line flow in the red color marking, the effect of this zone is less. In the second zone from 436-434 the effect shown in yellow color marking at this zone the temperature is decrease slowly in the step. 


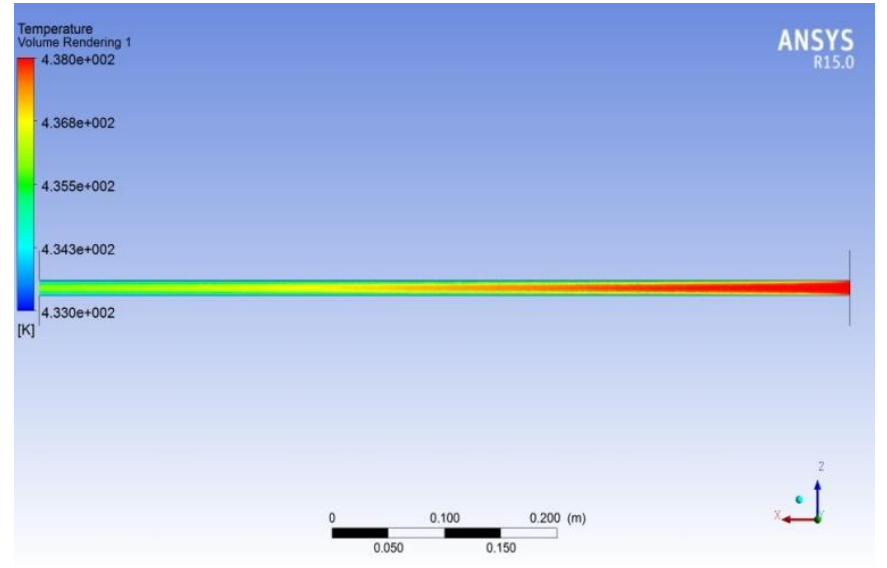

Fig-4: Temperature profile inside the die

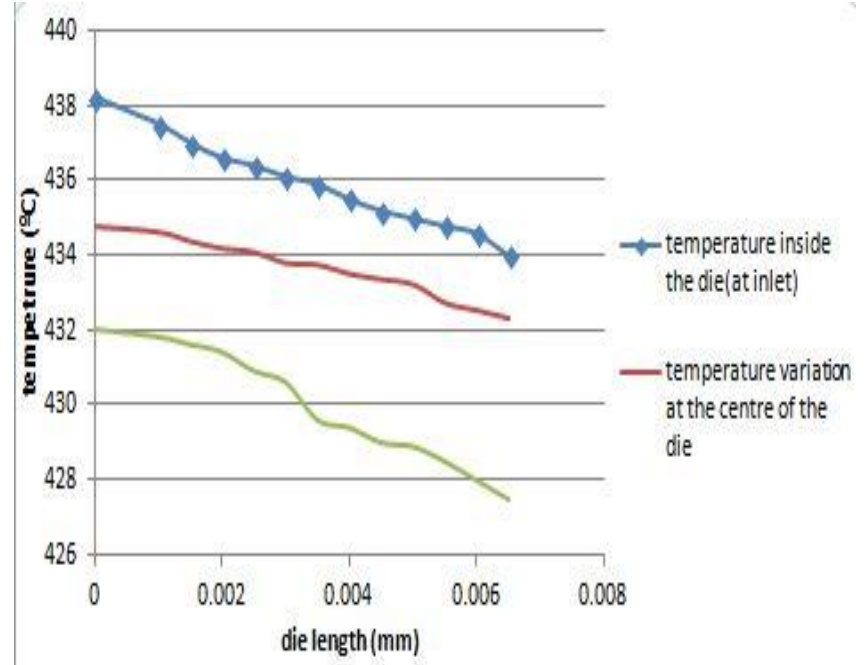

Chart-1: Development of temperature inside the die at inlet, centre and outlet

Temperature along length of die (Kelvin)

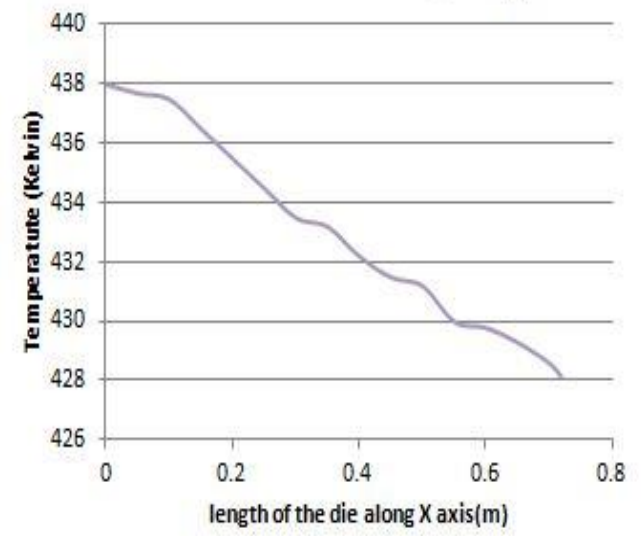

Temperature along the die length

Chart-2: Temperature variations inside the die along $X(\mathrm{~m})$ axis

In the third zone from $434-431^{\circ} \mathrm{K}$ the stream is shown in green color marking, the effect of this temperature range is moderate. In the fourth zone from $431-428^{\circ} \mathrm{K}$ the effect is shown in blue color marking the area of this zone is high. The temperature inside the die is decreasing variably from inlet to outlet of the die. And there value is closed to the practical value of Polypropylene molten temperature which shown validated result of temperature is shown.

As shown in the Graph1 the temperature profile is as expected and their results are validating with experimental results. The mean temperature of the die is $436^{\circ} \mathrm{K}$, inlet temperature is $438^{\circ} \mathrm{K}$, outlet temperature is $428^{\circ} \mathrm{K}$ and the final temperature is $443^{\circ} \mathrm{K}$. The CFD value was closer to the practical value of temperature of molten polymer at $437^{\circ} \mathrm{K}$

\section{CONCLUSION}

The significant process parameter for single screw extrusion of Polypropylene (M-12RR grade) is die temperature for both tensile strength and \% elongation.

The optimum values of process parameters for both tensile strength and percentage elongation was observed as, barrel temperature $160^{\circ} \mathrm{C}$, die temperature $165^{\circ} \mathrm{C}$ and screw speed of $50 \mathrm{rpm}$

The maximum percentage elongation at peak was observed as $5.504 \%$. The maximum value of percentage at elongation for peak occurred for sample no. 3 .

The maximum tensile strength at peak was 25.946 MPa. The maximum value of strength for peak occurred for sample no 3.

It can be seen from the result obtained from the experimental graph value is closer proximity with CFD graph values for temperature. The research successfully validates the use of CFD for investigate the process parameter inside the die of single screw extruder.

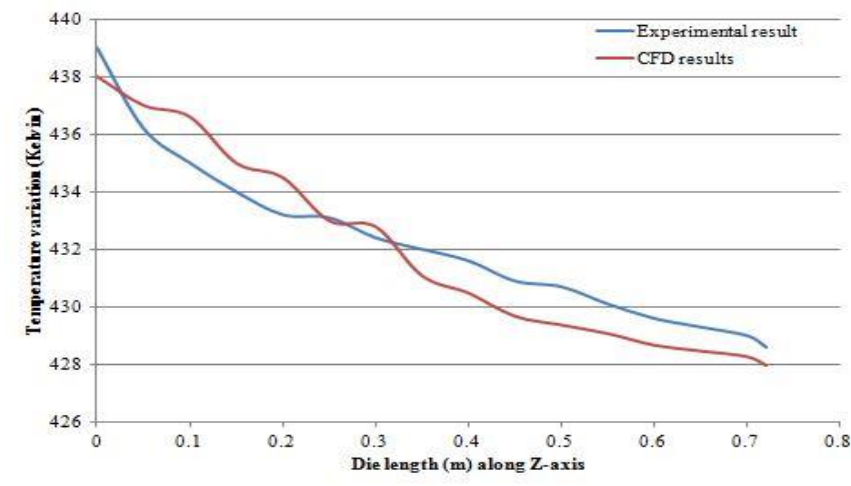

Chart 3: Comparison results of experimental result and CFD result

\section{REFERENCES}

[1] Boparai K Singh, Singh R, Singh H. (2016), "Experimental Investigations for Development of Nylon6Al-Al2O3 Alternative FDM Filament", Journal of Rapid Prototyping Journal, Vol. 22 Iss 4 pp 35-42.

[2] Chung I Chan., "Extrusion of Polymers"., Hanser publications, $2^{\text {nd }}$ editions. 
[3] I. Ben-Gal, (2005) "On the use of data compression measures to assess robust designs", IEEE Trans. On Reliability, Vol. 54, pp. 381-388.

[4]. Jayaraman, M., Sivasubramanian, R., Balasubramanian, V. and Lakshinarayanan, A.K. (2009), "Optimization of process parameters for friction stir welding of cast aluminium alloy A319 by Taguchi method", Journal of Scientific and Research, Vol. 68, pp.36-43.

[5]. Jareka Bogusław, Kubika Aleksandra., (2015) “The examination of the Glass Fiber Reinforced Polymer composite rods in terms of the application for concrete reinforcement", Journal of Procedia Engineering, Vol. 108, pp $394-401$.

[6]. Khan G.J., Dalu S.R., Gadekar S.S., (2014), "Defects in extrusion process and their impact on product quality" International journal of mechanical engineering and robotics research, Vol. 3, pp- 187-194.

[7]. Kumar.S, Bohat.M (2015), "Application of Taguchi Method in the Optimization of Cutting Parameters for Surface Roughness in Turning on EN-362 Steel", International Journal for Innovative Research in Science \& Technology Vol. 2, Issue 02, pp 263-267

[8]. Lewis Jennifer, Adams James, Geil Phil. (1995) "Introduction to polymers", Material science and technology Journal.

[9]. Lee S Chul., Cad dell M Robert. , (1972) "Cold extrusion and cold drawing of polymeric rod: The influence on subsequent tensile and compressive mechanical properties",Journal of Material science and technology, Vol. 10, pp 241-248.

[10]. Manohar.B and Periasamy.C, (2016), "Computational fluid dynamics simulation of single screw extruders in cable industries". IJRET: International Journal of Research in Engineering and Technology, Vol. 5, pp. 2319-1163.

[11]. Sakai Tadamoto., (2013) "Screw extrusion technology - past, present and future" Journal of Polimery, Vol. 58, pp 11-12.

[12]. Rao. N.P,"Manufacturing process book” edition II.

[13]. Singh.R and Ranjan.N (2017), "Experimental Investigation for Mechanical Properties of Polyvinyl Chloride Feed Stock Filament prepared with Twin-Screw Extruder", International Journal of Engineering \& Technology. 